\title{
Article
}

\section{Application of the Delphi technique in healthcare maintenance}

\author{
Njuangang, Stanley, Liyanage, Champika Lasanthi and Akintoye, \\ Akintola \\ Available at http://clok.uclan.ac.uk/13955/ \\ Njuangang, Stanley ORCID: 0000-0002-9325-3749, Liyanage, Champika \\ Lasanthi ORCID: 0000-0001-6687-3611 and Akintoye, Akintola ORCID: 0000- \\ 0002-0611-5824 (2017) Application of the Delphi technique in healthcare \\ maintenance. International Journal of Health Care Quality Assurance, 30 (8). \\ pp. 737-754. ISSN 0952-6862
}

It is advisable to refer to the publisher's version if you intend to cite from the work. http://dx.doi.org/10.1108/JJHCQA-02-2017-0042

For more information about UCLan's research in this area go to http://www.uclan.ac.uk/researchgroups/ and search for < name of research Group>.

For information about Research generally at UCLan please go to http://www.uclan.ac.uk/research/

All outputs in CLoK are protected by Intellectual Property Rights law, including Copyright law. Copyright, IPR and Moral Rights for the works on this site are retained by the individual authors and/or other copyright owners. Terms and conditions for use of this material are defined in the policies page.

\section{CLoK}

Central Lancashire online Knowledge www.clok.uclan.ac.uk

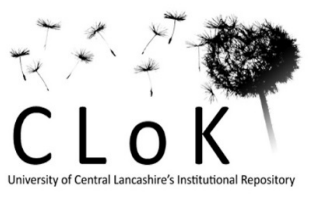




\title{
eEmerald $\begin{aligned} & \text { International Journal of } \\ & \text { Health Care Quality Assurance }\end{aligned}$
}

\section{Application of the Delphi Technique in Healthcare Maintenance}

\begin{tabular}{|r|l|}
\hline Journal: & International Journal of Health Care Quality Assurance \\
\hline Manuscript ID & IJHCQA-02-2017-0042 \\
\hline Manuscript Type: & Original Article \\
\hline Keywords: & Case study, Critical Success Factors, Delphi, Healthcare maintenance, NHS \\
\hline \multicolumn{2}{|c}{} \\
\hline
\end{tabular}

\author{
SCHOLARONE \\ Manuscripts
}


Table 1: Assigning Codes to the Research Materials

\begin{tabular}{|c|c|c|c|c|c|}
\hline 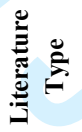 & No & Title & Publishing Body & Year & $\begin{array}{l}\text { Assigned } \\
\text { Codes }\end{array}$ \\
\hline \multirow{7}{*}{ 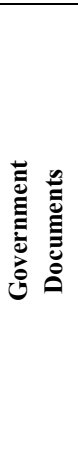 } & 1 & Reducing Healthcare Associated Infection in Hospitals in England & House of Commons & 2009 & GD-1 \\
\hline & 2 & $\begin{array}{l}\text { The Health and Social Care Act 2008: code of practice for the } \\
\text { prevention and control of healthcare associated infections and } \\
\text { related guidance }\end{array}$ & $\begin{array}{l}\text { Department of } \\
\text { Health }\end{array}$ & 2009 & $G D-2$ \\
\hline & 3 & $\begin{array}{l}\text { Improving Patient Care by Reducing the Risk of HAI: A progress } \\
\text { report }\end{array}$ & $\begin{array}{l}\text { National Audit } \\
\text { Office }\end{array}$ & 2004 & $G D-3$ \\
\hline & 4 & Towards Cleaner Hospitals and Lower Rates of Infections & $\begin{array}{l}\text { Department of } \\
\text { Health }\end{array}$ & 2004 & $G D-4$ \\
\hline & 5 & Winning Ways: working together to reduce HCAI in England & $\begin{array}{l}\text { Department of } \\
\text { Health }\end{array}$ & 2003 & GD-5 \\
\hline & 6 & $\begin{array}{l}\text { Getting Ahead of the Curve: a strategy for combating infectious } \\
\text { diseases }\end{array}$ & $\begin{array}{l}\text { Department of } \\
\text { Health }\end{array}$ & 2002 & $G D-6$ \\
\hline & 7 & $\begin{array}{l}\text { The Management and Control of HAI in the NHS Trusts in } \\
\text { England }\end{array}$ & $\begin{array}{l}\text { National Audit } \\
\text { Office }\end{array}$ & 2000 & GD-7 \\
\hline \multirow{10}{*}{ 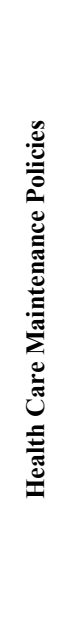 } & 8 & Maintenance Policy for Estates: (including Planned \& Preventative) & NHS Plymouth & 2011 & $H M-8$ \\
\hline & 9 & Estates Services Management Policy & $\begin{array}{l}\text { Berkshire NHS } \\
\text { Trusts }\end{array}$ & 2011 & $H M-9$ \\
\hline & 10 & $\begin{array}{l}\text { Infection Control in the Built Environment Policy: (A Guide for } \\
\text { Estates, Infection Control \& Property Services, Capital Planning } \\
\text { Teams, Managers \& Clinical Teams) }\end{array}$ & NHS Fort Valley & 2010 & $H M-10$ \\
\hline & 11 & Estate Maintenance Policy & $\begin{array}{l}\text { Northamptonshire } \\
\text { NHS Trust }\end{array}$ & 2010 & HM-11 \\
\hline & 12 & Policy for the Maintenance of PCT Premises & NHS Kirklees & 2009 & HM-12 \\
\hline & 13 & $\begin{array}{l}\text { Estates Maintenance Policy: (Including Planned Preventative } \\
\text { Maintenance) }\end{array}$ & $\begin{array}{l}\text { Yeovil NHS } \\
\text { Foundation Trust }\end{array}$ & 2009 & HM-13 \\
\hline & 14 & $\begin{array}{l}\text { Policy for Planned Preventative Maintenance - Estates: (Required } \\
\text { by Health Act 2006) }\end{array}$ & $\begin{array}{l}5 \text { Boroughs } \\
\text { Partnership NHS } \\
\text { Trust }\end{array}$ & 2009 & HM-14 \\
\hline & 15 & Estates Maintenance Policy & NHS Shetland & 2008 & HM-15 \\
\hline & 16 & Estates \& Facilities Management General Policy & $\begin{array}{l}\text { South Tees NHS } \\
\text { Trusts }\end{array}$ & 2008 & $H M-16$ \\
\hline & 17 & $\begin{array}{l}\text { Infection Control Guidelines for Maintenance Staff: (Estates, } \\
\text { Facilities, Hotel Services) }\end{array}$ & $\begin{array}{l}\text { Barnet, Enfield \& } \\
\text { Haringey NHS Trust }\end{array}$ & 2004 & HM-17 \\
\hline \multirow{10}{*}{ 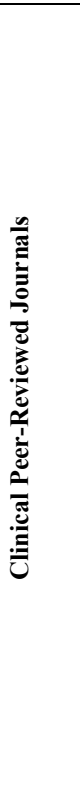 } & 18 & $\begin{array}{l}\text { Airborne Aspergillus contamination during hospital construction } \\
\text { works: Efficacy of protective measures }\end{array}$ & $\begin{array}{l}\text { Association for } \\
\text { Professionals in } \\
\text { Infection Control } \\
\text { and Epidemiology }\end{array}$ & 2010 & CR-18 \\
\hline & 19 & $\begin{array}{l}\text { Prospective survey of indoor fungal contamination in hospital } \\
\text { during a period of building construction }\end{array}$ & $\begin{array}{l}\text { Journal of Infection } \\
\text { Control }\end{array}$ & 2007 & CR-19 \\
\hline & 20 & $\begin{array}{l}\text { Undetected Bacillus pseudo-outbreak after renovation work in a } \\
\text { teaching hospital }\end{array}$ & $\begin{array}{l}\text { British Infection } \\
\text { Control Society }\end{array}$ & 2006 & $C R-20$ \\
\hline & 21 & $\begin{array}{l}\text { A cluster of deep bacterial infections following eye surgery } \\
\text { associated with construction dust }\end{array}$ & $\begin{array}{l}\text { The Hospital } \\
\text { Infection Society }\end{array}$ & 2006 & $C R-21$ \\
\hline & 22 & $\begin{array}{l}\text { Fungal contamination of air conditioning units in operating theatres } \\
\text { in India }\end{array}$ & $\begin{array}{l}\text { Journal of Hospital } \\
\text { Infection }\end{array}$ & 2005 & $C R-22$ \\
\hline & 23 & $\begin{array}{l}\text { Outbreak of Invasive Aspergillus Infection in Surgical Patients, } \\
\text { Associated with a Contaminated Air-Handling System }\end{array}$ & $\begin{array}{l}\text { Clinical Infectious } \\
\text { Diseases }\end{array}$ & 2003 & $C R-23$ \\
\hline & 24 & $\begin{array}{l}\text { Demolition of a hospital building by controlled explosion: the } \\
\text { impact on filamentous fungal load in internal and external air }\end{array}$ & $\begin{array}{l}\text { Journal of Hospital } \\
\text { Infection }\end{array}$ & 2002 & $C R-24$ \\
\hline & 25 & $\begin{array}{l}\text { A Cluster of Invasive Aspergillosis in a Bone Marrow Transplant } \\
\text { Unit Related to Construction and the Utility of Air Sampling }\end{array}$ & $\begin{array}{l}\text { Division of } \\
\text { Infectious Diseases, } \\
\text { University of } \\
\text { Massachusetts }\end{array}$ & 2001 & $C R-25$ \\
\hline & 26 & $\begin{array}{l}\text { A prospective study on factors influencing aspergillus spore load in } \\
\text { the air during renovation works in a neonatal intensive care unit }\end{array}$ & $\begin{array}{l}\text { Journal of Hospital } \\
\text { Infection }\end{array}$ & 2000 & $C R-26$ \\
\hline & 27 & $\begin{array}{l}\text { Air sampling for Aspergillus spp. during building activity in a } \\
\text { paediatric hospital ward }\end{array}$ & $\begin{array}{l}\text { Department of } \\
\text { Microbiology } \\
\text { Yorkhill NHS Trust }\end{array}$ & 1995 & CR-27 \\
\hline
\end{tabular}


Table 2: The CSFs and Performance Measures Identified in the Literature

\begin{tabular}{|c|c|c|}
\hline $\begin{array}{l}\text { A) } \\
\text { BSC } \\
\text { Perspective }\end{array}$ & $\begin{array}{l}\text { B) } \\
\text { CSFs } \\
(n=8)\end{array}$ & $\begin{array}{l}(\mathrm{C}) \\
\text { Performance Measures } \\
(\mathrm{n}=56)\end{array}$ \\
\hline \multirow{42}{*}{$\begin{array}{l}\text { Internal } \\
\text { Business } \\
\text { Processes }\end{array}$} & \multirow{6}{*}{$\begin{array}{l}\text { 1. Liaise \& } \\
\text { Communicate } \\
\text { with the } \\
\text { Infection Control } \\
\text { Team (ICT) }\end{array}$} & Early consultation \& authorisation from the Infection Control Team (ICT). \\
\hline & & 2. $\quad$ Seek the advice from the Infection Control Team (ICT). \\
\hline & & Liaise with person in charge of work areas. \\
\hline & & 4. System for maintenance staff to liaise with domestic staff. \\
\hline & & Communication channel between maintenance staff and contracted staff. \\
\hline & & Regular meetings between maintenance \& ICT members. \\
\hline & $\begin{array}{l}\text { 2. Infection Control } \\
\text { Practices }\end{array}$ & \\
\hline & \multirow{8}{*}{$\begin{array}{l}- \text { Cleaning } \\
\text { Requirements }\end{array}$} & Active means to prevent airborne dust from dispersing. \\
\hline & & 8. Compliance with hand hygiene whilst working in clinical areas. \\
\hline & & 9. Compliance with the use of personal protective equipment. \\
\hline & & 10. Report any injury especially if 'sharp'-related, cover wounds or sores. \\
\hline & & 11. Restriction of maintenance staff with symptoms of infection in clinical areas. \\
\hline & & 12. Conduct maintenance work in a manner that facilitates cleaning. \\
\hline & & 13. Temporary hand-washing facilities for maintenance staff working in clinical areas. \\
\hline & & 14. Wash and sanitise drainage equipment after use. \\
\hline & \multirow{5}{*}{$\begin{array}{l}\text { - Administrative } \\
\text { Requirement }\end{array}$} & 15. Inform Charge Nurse before commencement of maintenance work. \\
\hline & & 16. Maintain and review infection control policies and procedures. \\
\hline & & 17. Obtain infection control permit, and assess patients for risk of infections \\
\hline & & 18. Provide safe working system for maintenance staff in infection prevention. \\
\hline & & 19. Pre-employment health check and immunisation programme for all maintenance staff \\
\hline & \multirow{4}{*}{$\begin{array}{l}- \text { Transport } \\
\text { Requirements }\end{array}$} & 20. Health \& safety signage used. \\
\hline & & 21. Contain construction waste before transport in tightly covered containers. \\
\hline & & $\begin{array}{l}\text { 22. Transport clean and sterile equipment to storage areas via route that minimises } \\
\text { contamination. }\end{array}$ \\
\hline & & 23. Redirect pedestrian traffic from work area. \\
\hline & 3. SLA Agreement & 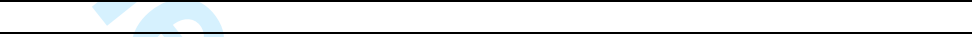 \\
\hline & \multirow{6}{*}{$\begin{array}{r}\text { - Contract } \\
\text { Requirements with } \\
\text { External Providers }\end{array}$} & 24. Contractor's adherence to safe record keeping, and mandatory code of conduct in IC \\
\hline & & 25. Contractor's ability to respond to emergency calls. \\
\hline & & 26. Account for changes in assets and legislation when renewing contracts. \\
\hline & & 27. Contractor's procedure to supervise maintenance work and variables, e.g. spares, etc. \\
\hline & & $\begin{array}{l}\text { 28. Select contractors for their strong technical, resource, managerial, and communication } \\
\text { capabilities. }\end{array}$ \\
\hline & & 29. Customer satisfaction survey as part of SLA \\
\hline & \multirow{2}{*}{$\begin{array}{l}\text { - Contracted Staff } \\
\text { Requirements }\end{array}$} & 30. Contractor's responsibility for any unsafe equipment or practice. \\
\hline & & 31. Contracted workers attendance to all mandatory induction and training. \\
\hline & \multirow{5}{*}{$\begin{array}{l}\text { 4. Maintenance } \\
\text { Strategies }\end{array}$} & 32. Timely execution of all planned maintenance work posing risk of infection. \\
\hline & & 33. Record of the effectiveness of all critical maintenance equipment/assets. \\
\hline & & 34. Application of computer-based maintenance system. \\
\hline & & 35. Daily check of all critical maintenance systems. \\
\hline & & $\begin{array}{l}\text { 36. Categorize hospital assets and maintenance equipment into significant and non- } \\
\text { significant items. }\end{array}$ \\
\hline & \multirow{4}{*}{ 5. Risk Assessment } & 37. Involve all stakeholders in risk identification and response. \\
\hline & & 38. Staff education \& clear lines of individual responsibility \\
\hline & & 39. Process for reporting, managing, and analysing complaints and incidences. \\
\hline & & 40. Use of a recognised risk assessment tool. \\
\hline \multirow{4}{*}{ Financial } & \multirow{4}{*}{$\begin{array}{l}\text { 6. Maintenance } \\
\text { Resource } \\
\text { Availability }\end{array}$} & 41. Adequate resources for mandatory and operational compliance in IC. \\
\hline & & $\begin{array}{l}\text { 42. Review of hospital building services and infrastructure to feed into investment } \\
\text { program. }\end{array}$ \\
\hline & & 43. The purchase of quality maintenance materials and products from reliable suppliers. \\
\hline & & 44. Monthly review of expenditure against budget in IC. \\
\hline & $\begin{array}{ll}\text { 7. } & \text { Staff } \\
& \text { Education }\end{array}$ & \\
\hline \multirow{8}{*}{$\begin{array}{l}\text { Innovation } \\
\text { and } \\
\text { Learning }\end{array}$} & \multirow{4}{*}{ - $\quad$ Staff Training } & 45. Availability of information on statutory and technical guidance on IC. \\
\hline & & 46. Employment of skilled and competent staff \\
\hline & & 47. Annual review of staff training. \\
\hline & & 48. Site induction on infection control within first few weeks of employment. \\
\hline & \multirow{4}{*}{$\begin{array}{ll}- & \text { Staff } \\
\text { Development }\end{array}$} & 49. Representation of maintenance department in IC committees. \\
\hline & & 50. Education of maintenance staff on assessing and managing the risk of infection. \\
\hline & & 51. Staff team briefings and appraisal schemes in IC. \\
\hline & & 52. Equal access, and improve working lives for staff. \\
\hline \multirow{4}{*}{$\begin{array}{l}\text { Customer } \\
\text { Satisfaction }\end{array}$} & \multirow{4}{*}{$\begin{array}{l}\text { 8. Customer } \\
\text { Satisfaction }\end{array}$} & $\begin{array}{l}\text { 53. System to review, analyse complaints against maintenance services, and recommend } \\
\text { improvement. }\end{array}$ \\
\hline & & 54. Measure the speed to response to maintenance request. \\
\hline & & 55. Measure the number of maintenance products that do not conform to the request. \\
\hline & & 56. Available complaint boxes/leaflets \\
\hline
\end{tabular}


Table 3: Research and Interview Questions

\begin{tabular}{|c|c|}
\hline $\begin{array}{l}\text { Research Questions identified } \\
\text { from the literature review }\end{array}$ & Interview questions \\
\hline $\begin{array}{l}\text { A. Do healthcare maintenance } \\
\text { managers manage the } \\
\text { performance of their services in } \\
\text { infection control? }\end{array}$ & $\begin{array}{l}\text { 1. Can you describe the vision, strategy, and objectives of your } \\
\text { NHS Trust in infection control? } \\
\text { 2. Can you describe the vision, strategy, and objectives of the } \\
\text { facilities management (FM) directorate in infection control, and } \\
\text { how are they aligned to those of the NHS trust? } \\
\text { 3. Does the healthcare maintenance unit have a mission statement } \\
\text { in infection control? } \\
\text { 4. What are the key issues in infection control addressed by the } \\
\text { mission statement? } \\
\text { 5. How are these issues addressed in the mission statement aligned } \\
\text { to the strategy of NHS trust/FM directorate in infection control? }\end{array}$ \\
\hline $\begin{array}{l}\text { B. Do healthcare maintenance units } \\
\text { have performance management } \\
\text { tool to measure performance in } \\
\text { infection control? }\end{array}$ & $\begin{array}{l}\text { 6. Has the healthcare maintenance unit identified its maintenance } \\
\text { activities in infection control? } \\
\text { 7. Can you identify these maintenance activities? } \\
\text { 8. Does the healthcare maintenance division categorise critical } \\
\text { success factors and measures according to the four perspective } \\
\text { of the BSC? }\end{array}$ \\
\hline $\begin{array}{l}\text { C. What form of performance } \\
\text { measurement tool will healthcare } \\
\text { maintenance units adopt in } \\
\text { infection control? }\end{array}$ & $\begin{array}{l}\text { 9. What are the critical success factors in healthcare maintenance } \\
\text { in infection control? } \\
\text { 10. List the performance measures in infection control for each key } \\
\text { performance indicator }\end{array}$ \\
\hline $\begin{array}{l}\text { D. What are the key performance } \\
\text { management goals and measures } \\
\text { in healthcare maintenance in the } \\
\text { control of HAIs in the NHS? }\end{array}$ & $\begin{array}{l}\text { 11. Has the healthcare maintenance division formulated goals for } \\
\text { the performance indicators and measures? } \\
\text { 12. What are the goals of the healthcare maintenance for the } \\
\text { different performance indicators and measures in infection } \\
\text { control? } \\
\text { 13. How are these goals aligned to the overall strategy of the NHS } \\
\text { trust/FM directorate in infection control? } \\
\text { 14. Has the healthcare maintenance unit set strategic objectives and } \\
\text { targets to be met in line with the different performance } \\
\text { indicators in infection control? }\end{array}$ \\
\hline $\begin{array}{l}\text { E. Do the healthcare maintenance } \\
\text { unit liaise with other } \\
\text { stakeholders in the identification } \\
\text { of CSFs and performance } \\
\text { measures in IC? }\end{array}$ & $\begin{array}{l}\text { 15. Does the healthcare maintenance unit liaise with relevant } \\
\text { stakeholders in developing performance indicators and } \\
\text { measures? } \\
\text { 16. Who are these relevant stakeholders? } \\
\text { 17. What role do they play in identifying performance indicators } \\
\text { and measures in infection control? }\end{array}$ \\
\hline
\end{tabular}


Table 4: Analysis of the Pilot Case Study Results

\begin{tabular}{|c|c|c|c|c|c|c|c|c|}
\hline \multirow[b]{2}{*}{$\begin{array}{l}\text { Interview } \\
\text { questions }\end{array}$} & \multicolumn{4}{|c|}{ Case 1} & \multicolumn{4}{|c|}{ Case 2} \\
\hline & No & Yes & Some & $\begin{array}{l}\text { Remark/indicators/ } \\
\text { measures }\end{array}$ & No & Yes & Some & $\begin{array}{l}\text { Remark/indicators/ } \\
\text { measures }\end{array}$ \\
\hline A-1 & $\sqrt{ }$ & & & $\begin{array}{l}\text { According to } \\
\text { respondents, this } \\
\text { was the } \\
\text { responsibility of } \\
\text { members of the } \\
\text { infection control } \\
\text { team }\end{array}$ & $\sqrt{ }$ & & & $\begin{array}{l}\text { Manager generally did not } \\
\text { understand the meaning of } \\
\text { 'vision', 'mission } \\
\text { statement' and 'objectives' }\end{array}$ \\
\hline A-2 & $\sqrt{ }$ & & & & $\sqrt{ }$ & & & \\
\hline A-3 & $\sqrt{ }$ & & & & $\sqrt{ }$ & & & \\
\hline A-4 & $\sqrt{ }$ & & & & $\sqrt{ }$ & & & \\
\hline A-5 & $\sqrt{ }$ & & & & $\sqrt{ }$ & & & \\
\hline B-6 & & & $\sqrt{ }$ & & $\sqrt{ }$ & & & \\
\hline B-7 & & & $\sqrt{ }$ & $\begin{array}{l}\text { Hand-washing } \\
\text { compliance, } \\
\text { legislative } \\
\text { compliance } \\
\end{array}$ & $\sqrt{ }$ & & & \\
\hline B-8 & $\sqrt{ }$ & & & & $\sqrt{ }$ & & & \\
\hline C-9 & $\sqrt{ }$ & & & & $\sqrt{ }$ & & & \\
\hline $\mathrm{C}-10$ & $\sqrt{ }$ & & & & $\sqrt{ }$ & & & \\
\hline $\mathrm{D}-11$ & $\sqrt{ }$ & & & & $\sqrt{ }$ & & & \\
\hline D-12 & $\sqrt{ }$ & & & & $\sqrt{ }$ & & & \\
\hline D-13 & $\sqrt{ }$ & & & & $\sqrt{ }$ & & & \\
\hline D-14 & $\sqrt{ }$ & & & & $\sqrt{ }$ & & & \\
\hline E-15 & $\sqrt{ }$ & & & & $\sqrt{ }$ & & & \\
\hline E-16 & & & & $\begin{array}{l}\text { Infection control } \\
\text { team }\end{array}$ & & & & Infection control team \\
\hline E-17 & & & $\sqrt{ }$ & $\begin{array}{l}\text { Advice on infection } \\
\text { control, organise } \\
\text { workshop on } \\
\text { legionnaires 'disease }\end{array}$ & & & $\sqrt{ }$ & $\begin{array}{l}\text { Advice on infection } \\
\text { control issues }\end{array}$ \\
\hline
\end{tabular}


Figure 1: A typical Three-Round Delphi Process 


\section{Application of the Delphi Technique in Healthcare Maintenance}

Purpose - This research examines the research design, issues and considerations in the application of the Delphi technique to identify, refine and rate the critical success factors $(\mathrm{CSFs})$ and performance measures in maintenance-associated infections.

Design/methodology/approach - In-depth literature review through the application of open and axial coding were applied to formulate the interview and research questions. These were used to conduct an exploratory case study of two healthcare maintenance managers, randomly selected from two NHS Foundation Trusts in England. The results of exploratory case study provided the rationale for the application of the Delphi technique in this research. The different processes in the application of the Delphi technique in healthcare research are examined thoroughly.

Finding - This research demonstrates the need to apply and integrate different research methods to enhance the validity of the Delphi technique. The result of first round of the Delphi exercise is a useful contribution in its own rights. It identified a number of salient issues and differences in the opinions of the Delphi participants, noticeably between healthcare maintenance managers and members of the infection control team. It also resulted in useful suggestions and comments to improve the quality and presentation of the secondand third-round Delphi instruments.

Practical implications - This research provides a research methodology that can be adopted by researchers investigating new and emerging issues in the healthcare sector. As this research demonstrates, the Delphi technique is relevant in soliciting expert knowledge and opinion to identify performance measures to control maintenance-associated infections in hospitals. The methodology provided here could be applied by other researchers elsewhere to probe, investigate and generate rich information about new and emerging healthcare research topics.

Originality/value - We demonstrate how different research methods can be integrated to enhance the validity of the Delphi technique. For example, the results of an exploratory case study provided the rationale for the application of the Delphi technique investigating the key 


\begin{abstract}
performance measures in maintenance-associated infections. The different processes involved
\end{abstract} in the application of the Delphi technique are also carefully explored and discussed in depth.

Keywords: Case study, critical success factors, Delphi, healthcare maintenance, infection control, NHS, performance measures.

\title{
Introduction
}

This research centres on the performance of healthcare maintenance services in the control of hospital-acquired infections (HAIs) in the NHS. In addition to examining the different research processes in the formulation of the research and interview questions, a rationale is provided about the application of the Delphi technique investigating the control of HAIs in maintenance services in the National Health Service (NHS). The level of iteration between the infection control members and healthcare maintenance managers resulted in consensus in the refinement and identification of the critical success factors (CSFs) and key performance measures to control maintenance-associated infections in hospitals.

\section{Literature Review}

HAIs are a major cause of deaths and increased morbidity, especially in immunecompromised patients (Parliamentary Office of Science and Technology (POST), 2003). Of all the healthcare facilities management services (i.e. cleaning, waste management, etc.), healthcare maintenance, despite its strong association with HAI, is one of the least investigated. It has been shown, for example, that the malfunctioning and contamination of heating, ventilation and air conditioning systems (HVAC) because of dust and moisture, increases the risk of the spread of environmental fungi and bacteria in hospitals (Joseph, 2006).

This indicates a need for healthcare officials to tackle the root causes of maintenanceassociated infections (infections caused by the poor performance of healthcare maintenance services in infection control (IC)) in hospitals. One way to achieve this is by improving the performance of the healthcare maintenance unit in IC by identifying relevant performance measures. Attempts to identify this through the application of an exploratory case study did not produce significant results. The exploratory case study involved two NHS Foundation Trust hospitals that were randomly selected in the North West of England. Results showed that the two healthcare maintenance managers who participated in the study lacked knowledge and understanding in the area of the control of maintenance-associated infection. 
This indicated that the case study approach was not a suitable way of finding answers to the research and interview questions that had been formulated. Reviews of alternative research methods, i.e. interviews and a questionnaire survey, pointed to the Delphi technique.

The Delphi technique was therefore applied because it allows researchers to recruit professionals who then "focus their collective human intelligence on the problem at hand" (Linstone and Turoff, 1975, as cited in Skulmoski et al., 2007: p. 2). Besides offering anonymity to respondents, Delphi also makes it possible for researchers to recruit professionals from a wide geographical area. In the proceeding section, we examine the different steps and rationale resulting in the application of the Delphi technique to identify the CSFs and performance measures in the control of maintenance associated infections.

\section{The Document Selection and Analyses}

The first part of the literature review process involved the selection of relevant research materials for the grounded theory analysis. The research materials were scrutinised for authenticity, credibility and meaningfulness. Appropriate criteria were also applied in the search relevant documents from the different databases. The researchers identified 27 research documents for identifying performance related issues to control maintenanceassociated infections in hospitals.

As shown Table I, the research documents were drawn from three different main sources; and assigned the following unique codes GD (1 - 7), HM (8 - 17), and CR (18 - 27). Seven of the research documents were drawn from government documents; the remaining twenty research documents were divided equally between healthcare maintenance policies (HMPs) and clinical peer-reviewed journals. Because of the nature of the research, it was difficult to find research materials focusing exclusively on maintenance associated infections. Therefore, the criteria for selecting the research documents were based on inferential judgment of what actually constituted maintenance work in the clinical literature. In the next section, focus is on two processes i.e. open coding and axial coding applied to investigate performance issues in the control of maintenance associated infections.

\section{Insert Table I}




\section{Open Coding to Identify CSFs in Maintenance-Associated Infections}

After the selection process, the next step was to conduct open coding to identify issues related to the performance of maintenance-associated infections in hospitals. The process of open coding was carried out using QRS NVivo8.

Twenty-seven research documents were uploaded, followed by the categorisation of different themes into 'parent nodes' - a container in which words, sentences, ideas, or paragraphs with similar connotations were coded. On many occasions, as new information emerged from analysing the documents, a 'parent node' was combined with another or its name refined or deleted altogether. The process only stopped when it became clear that all the 'parent nodes' had been identified. The eight 'parent nodes' identified through open coding were interpreted as the Critical success factors (CSFs) in the control of maintenanceassociated infections (Table II).

\section{Axial Coding to Identify the Performance Measures}

During axial coding, 'child nodes' were developed for some of the 'parent nodes'. For example, for the 'parent node' infection control practices, six 'child nodes' were identified i.e. cleaning practices, hand hygiene and maintenance staff practices, etc. On several occasions during axial coding, the newly developed child notes were refined or deleted altogether. The Child nodes offered clarity about the understanding of some of the parent nodes.

After the development of the final 'child nodes', specific-related themes identified in the source documents were coded appropriately, and considered as the performance measures.

Both the CSFs and performance measures were further categorised according to the four perspectives of the balanced scorecard (BSC) namely financial, internal business processes, innovation and learning, and customer satisfaction (see Table II). Tsang et al_(1998) advised against considering maintenance as a purely tactical issue. The BSC therefore allows data to be collected on the financial and non-financial performance measures. By refining the themes that have been coded in the CFSs, the researchers were able to identify 56 performance measures to control maintenance-associated HAIs (see Table II).

The result of the document analyses was used to develop the research and interview questions for conducting the exploratory case study.

\section{Insert Table II}




\section{An Exploratory Case Study - Justification of the Delphi Technique}

The exploratory case study provided an overall insight about the performance measurement of maintenance associated infections in the NHS. It was also about making sure that the research focused on the main issues intended for investigation. Employing the exploratory case study does not mean that it will be used to investigate the final research questions and hypotheses (Yin, 1993). The exploratory case study makes it possible for a research topic of this nature to be seen through many lenses.

The exploratory case study was conducted with two Acute NHS hospitals in the North West of England; no criteria were used to select the cases. Both hospitals have a capacity of over six hundred beds, and employ over thirty healthcare maintenance staff. The exploratory case study was designed to elicit information from members of the infection control team and healthcare maintenance managers. However, it started with healthcare maintenance managers in order to assess their level of understanding of IC issues.

Data was collected in the exploratory case study through semi-structured interviews. The exploratory case study was conducted face-to-face at the respondents' place of work and recorded digitally. Table III show the five research questions (A, B, C, D and E) and seventeen interview questions (1-17) employed in the exploratory case study (the numbers used in Table III correspond to those used in Table IV). In order to facilitate reference and compilation, the interviews were labelled according to date, job description and the name of the NHS Trust. The recorded data was then transcribed and stored in a Word document. Because of the small number of cases, the results obtained from the exploratory case study were analysed manually.

The results of the exploratory case study revealed that healthcare maintenance managers selected for the study did not have the required level of knowledge in IC to participate further in this research study. As shown in Table IV, they generally lacked an understanding of the transmission of maintenance-associated infections. Neither of the two healthcare maintenance managers who participated in the exploratory case study could provide a complete answer to any of the seventeen interview questions they were asked. For example, they could not state the vision of their respective NHS Trusts in relation to IC. In both NHS Acute hospitals, managers did not measure performance in IC adequately. They applied only minimum levels of performance measurement for IC in order to achieve legislative compliance. 


\section{The Delphi Technique}

The Delphi technique can be defined as "a qualitative, long-range forecasting technique that elicits, refines, and draws upon the collective opinion and expertise of a panel of experts" (Gupta and Clarke, 1996: p. 185). Named after the Greek oracle, the Delphi technique has grown in popularity following the work of Helmer and Dalkey in 1963. Currently the technique is widely applied across many disciplines in the private and public sectors (Gordon, 1994). Since 1963, the Delphi technique has undergone a number of modifications. According to Hanafin (2004), significant modifications have produced three types of Delphi: classical, policy and decision. The word 'hybrid' Delphi is also used by Faucher et al. (2008) to describe any combination of these three types of Delphi.

In a classical Delphi, there is anonymity, iteration, controlled feedback, statistical group response, and stability in the responses experts provide on a specific issue. The central purpose of the policy Delphi is not only to reach consensus but also to generate policy alternatives through structured public dialogue. In the policy Delphi, there are polarised group responses and structured conflict (Hanafin, 2004). It is therefore a tool for the "analysis of policy issues and not a mechanism for making a decision" (Turoff, 2002: p. 80). As the name implies, decision Delphi is concerned with decisions relating to social development. Participation in the decision Delphi depends on one's position in the hierarchy. Although 

all those participating in the study. Despite trivial differences, the three types of Delphi have some features in common. According to Faucher et al. (2008), it is a process which is expertbased, managed, anonymous, indirectly interactive and iterative, and which generates controlled feedback and is aggregative and potentially asynchronous.

Although Delphi started as a technique for futures research, many researchers use it today to deal with complex issues (Linstone and Turoff, 2002). The design of the data collection instrument plays a critical role "for both the exploration and distillation" phases of the Delphi exercise (Day and Bobeva, 2005: p. 109). According to Day and Bobeva, creativity ensures that the Delphi questions meet the communication needs of the Delphi participants. Obviously, particular attention should also be given to the structure, length and content of the Delphi instrument. A review of the literature suggests that the number of rounds in Delphi studies is variable. According to Skulmoski et al. (2007) and Keeney et al. (2001), this depends on the time, purpose and nature of the study. Typically, three rounds of Delphi would be suitable for most studies.

One of the most important steps in a Delphi study concerns the nomination of participants (Hallowell and Gambatese, 2010). The credibility and reliability of Delphi studies depends on the quality of the participants selected (Keeney et al., 20010). However, it appears there are no exact criteria listed in the literature for the nomination of the Delphi participants (Hsu and Sandford, 2007). Hallowell and Gambatese (2010) describe the characteristics used to define 'experts' as equivocal in nature. One criterion used commonly by researchers is level of expertise. Generally, Delphi participants are supposed to be individuals who are directly affected by the research, have knowledge and experience, and are facilitators in the field of study (Day and Bobeva, 2005). Criteria proposed by Day and Bobeva include authorship, conference presentations and committee membership, etc. Irrespective of the nomination criteria employed in a study, researchers still have to make sure the Delphi participants are unbiased, as this has the potential to affect the generalisability of the results (Hallowell and Gambatese, 2010).

There are two methods of developing the first round Delphi research instrument. The first method is an inductive approach, whereby members of the panel freely generate new ideas about the topic (Powell, 2003). According to Millar (2000, as cited in Hanafin, 2004), this method takes too much time to analyse, and does not generate rich information. In the second method, the researcher generates ideas through the application of a qualitative 
research method like a literature review. In the second and third rounds of the Delphi exercise, participants arrive at a consensus on the issues under investigation. Reviews of the literature suggest that this can be achieved through the analysis of qualitative and/or quantitative data (Hsu and Sandford, 2007). Irrespective of the type of data, there is no standard criterion for defining and determining consensus in Delphi (Boote, Barber and Cooper, 2006). According to these authors, "the criterion for determining consensus appears ...to be an issue for the research team and their advisors". Therefore, in Delphi, authors apply several parametric and non-parametric statistical methods to arrive at consensus.

According to Kalaian and Kasim (2012), Delphi studies with more than 30 participants should apply parametric statistical methods such as the Coefficient of Variation (CV), the F-ratio, the Pearson correlation coefficient and the Paired t-test. In contrast, Delphi studies with fewer than 30 participants should apply non-parametric statistical methods such as McNemar, Spearman's Rank Correlation Coefficient, and the Wilcoxon Paired SignedRanks T Test.

\section{The Construction of the Delphi Instrument}

Figure 1 show the various processes involved in the application of Delphi in this research study. There are three Delphi rounds for identifying the CSFs and performance measures in healthcare maintenance in IC. The first round of the Delphi exercise solicits qualitative responses, while the second and third solicit quantitative responses from the Delphi participants. As there are few studies focusing on the area under investigation, the Delphi questions were developed mainly from different sources of literature, i.e. government documents, peer-reviewed infection control documents and healthcare maintenance policies. This method saves time, and acted as a stimulus for the Delphi participants to identify new CSFs and performance measures.

\section{Figure 1: A typical Three-Round Delphi Process}

The performance measures identified from the literature were categorised under eight CSFs: the availability of maintenance resources, maintenance strategies, risk assessment, IC practices, liaison and communication with the infection team, service level agreements, staff education and customer satisfaction. 56 performance measures were identified from the literature, and categorised under the eight CSFs. Both the CSFs and performance measures 
were used to develop the Delphi instrument that was piloted with healthcare personnel. A pilot Delphi study was conducted with colleagues to solicit suggestions about the presentation, wording and structure of the Delphi instrument. Through the pilot study, it was possible to test the appropriateness of the data analysis technique. The results obtained from the pilot study were used to improve the overall quality of the Delphi instrument.

\section{The Method for Arriving at Consensus}

In the current research, for a performance measure to be retained in a Delphi round, it needed to be interpreted as either very important or important in IC. Unimportant performance measures in IC were not retained. In the second and third rounds, participants were given the task of rating the level of importance of the different performance measures in healthcare maintenance in IC. The rating was based on a four point Likert scale. Scales 1 and 2 ('very important' and 'important') represented the positive category, while scales 3 and 4 ('unimportant' and 'very unimportant') represented the negative category. Thus, the following criteria were used to interpret the performance measures:

- Very important - at least $90 \%$ in the positive category

- Important - $80 \%$ to $89 \%$ in the positive category

Unimportant - 70\% - 79\% in the positive category

Very unimportant $-69 \%$ or below in the positive category

Although a performance measure might be interpreted as very important or important, it was not immediately retained in a Delphi round. The Delphi participants needed to arrive at a consensus that the performance measure was important in healthcare maintenance in IC. Having examined the different statistical techniques, consensus in this research study was determined through the application of the arithmetical mean (hereafter 'the mean'). The popularity of the mean as 'the most commonly used statistics of central tendency' (McDonald, 2009) makes it a suitable technique for establishing consensus in Delphi. Unlike other measures of central tendency, the mean takes into account every variable in the dataset (McDonald, 2009). A number of Delphi researchers, including Boote et al. (2006) and Green et al. (1990), also applied the mean to determine consensus in Delphi studies. The only disadvantage of the mean is that it might not be a suitable technique for much skewed data. The datasets in the current research did not exceed +2 or -2 . According to Garson of 


\begin{abstract}
Statistical Associates Publishing (2012), the skew or kurtosis for normally distributed data
\end{abstract} should be within the +2 and -2 range.

The scale ranges were established by a method similar to that used by Moravec (2007). It has been established by dividing the Likert scale range by the number of points on the Likert scale $(3 / 4)$. This produces an interval of approximately 0.75 . However, a more stringent interval of 0.72 is set for the high consensus level. For a performance measure to be retained in a Delphi round, the Delphi participants needed a group mean score of at least 3.28. Any performance measure with a group mean score of less than 3.28 was re-submitted to the Delphi participants for re-rating.

Most Delphi studies do not investigate how the different groups of participants rate the different factors or measures. Although the difference in the opinion of the two groups of Delphi participants in maintenance associated infections is reviewed here, it is beyond the scope of this research to discuss the results. The different in the opinion of the two groups of Delphi participants, i.e. healthcare maintenance managers and IC members was achieved through the application of the Mann-Whitney $U$ test. The Mann-Whitney $U$ test is a suitable technique for the comparison of samples that are not normally distributed (Wheater and Cook, 2005). The level of statistical significance in this study was set at $p=<0.05$.

\title{
The Selection of the Delphi Participants
}

In this research, the Delphi participants were purposively selected on the basis of their experience and knowledge of healthcare maintenance and IC. Since Delphi relies on expert opinion for credibility, stringent criteria were used for the selection of prospective Delphi participants. Prospective Delphi participants were considered eligible if:

1. They were directly involved with managing the performance of the healthcare maintenance unit in IC. This included healthcare maintenance managers and IC members (i.e. IC nurses and microbiologists).

2. They occupied the position of healthcare maintenance manager or IC member in an Acute NHS Trust, and had work experience in the same role for at least five years.

After stating the criteria for the selection of the Delphi participants, the next step was to decide on the number of Delphi participants. According to Powell (2003: p. 378) “...representativeness in Delphi is assessed on the qualities of the expert panel rather than its numbers" (Powell, 2003: p. 378). The contact details of prospective Delphi participants (i.e. 
healthcare maintenance managers and IC members) were located through professional databases and networking sites. In order to contact IC members, the database of the Infection Prevention Society (IPS) was utilised. One of the business functions of the IPS is influencing and promoting evidence-based research for infection prevention practice worldwide. In the search through the IPS database, contact details were sought only for its UK members who gave specific details of their role (i.e. microbiologist and infection control nurse) and worked for Acute NHS Trusts in England.

150 IC members were invited to participate in this Delphi study. As a basis for contacting healthcare maintenance managers, an online database containing the contact details of NHS estates and maintenance managers was purchased from Binley (2013 version). A search of their database produced the contact details of 170 healthcare maintenance managers working for Acute NHS Trusts in England.

The information gathered about the Delphi participants was used to create two Excel spreadsheets containing the titles, names, addresses, and telephone numbers of healthcare maintenance managers and IC members. 320 invitation letters were despatched via post to prospective Delphi participants across England. The letter stated the purpose and benefits of the study, as well as explaining issues of confidentiality and eligibility. Included with the invitation letters were self-addressed stamped envelopes, with a form for the Delphi participants to state their level of professional experience and email address. In order to increase participation, prospective Delphi participants were also asked to nominate colleagues for the Delphi exercise by giving their email addresses. Once the Delphi participants had provided email addresses, all subsequent correspondence was conducted via email. Besides the advantage of speed, 'email Delphi' enables researchers and Delphi participants to stay focused on the subject matter.

Of the 320 invitations sent to prospective Delphi participants via post, only $40(13 \%)$ were returned. However, because of issues with the returned forms, only $27(8.4 \%)$ NHS professionals were nominated for participation in the Delphi study. Of the remaining 13 Delphi nominees, four did not have the required level of work experience (set at five years). In three cases, the individuals had retired or no longer worked for the Acute NHS hospital. The last six forms contained email addresses that could not be read. Attempts to match the email addresses with names on the inventory did not help.

In order to increase the response rate, those who did not return their self-addressed stamped envelopes were contacted via telephone. However, with no response forthcoming 

after waiting for another week, the decision was taken to proceed with the Delphi study. Most Delphi studies only have between 8 and 16 participants (Hallowell and Gambatese, 2010). Therefore, 27 Delphi participants were considered enough. Of the 27 Delphi participants, 14 (52\%) were IC members and $13(48 \%)$ were healthcare maintenance managers. The information provided by the 27 Delphi participants was used to create an Excel spreadsheet containing the names of the Delphi nominees, their email addresses and the telephone numbers of their respective hospitals. Each Delphi nominee was assigned a unique code, which was to be used throughout the three rounds.

\section{The First Round of the Delphi Exercise}

The first-round Delphi instrument was designed to elicit qualitative responses from the Delphi participants. The Delphi instrument was divided into three main sections. In the first section, the Delphi participants were asked questions about their professional experience and area of specialisation. The second section contained a list of 56 performance measures (identified in the literature), which were categorised according to the eight CSFs in healthcare maintenance in IC. To provide better understanding and clarity, some of CSFs were divided into sub-categories. For example, under the CSF called 'infection control practice', the performance measures were grouped into three sub-categories: cleaning, transport, and administrative requirements. The Delphi participants were provided with a list of CSFs and performance measures and given the task of identifying new ones. Section three of the roundone Delphi instrument solicited feedback from the Delphi participants on the design, presentation, and wording of the Delphi instrument. The first-round Delphi instrument was distributed with detailed instructions on how to complete and return the Delphi instruments. Because the Delphi participants came from varied professional areas, the instruction notes also contained definitions of the key words (i.e. CSFs and performance measures) used in the Delphi instrument. To allow the Delphi participants enough time to complete the first-round Delphi exercises, they were given two weeks.

Although 27 NHS professionals agreed to take part in this research, not all of them returned the first-round Delphi instrument. 20 Delphi participants (74\%) returned the firstround Delphi instrument. Of these, 11 were IC members (55\%) and nine were healthcare maintenance managers $(45 \%)$. Attempts to increase the response rate by contacting the participants through emails and phone calls did not yield any result. The IC list was made up of five IC nurses and six consultant microbiologists. One of the consultants is a professor of 


\section{Subsequent Delphi Rounds}

The results of the first-round Delphi exercise were used to modify the second-round Delphi instrument. The Delphi participants identified 11 new performance measures in HM in IC. However, it was possible to add only six of these in the second round of Delphi questions as some of the round-one Delphi instruments were received only after the second round had started. The other five new performance measures were then included in the third-round questions. Therefore, in round two of the Delphi exercise, there were sixty-two performance measures grouped under eight CSFs.

In the second round of the Delphi exercise, participants were asked to rate on a Likert scale of four the importance of different performance measures in HM in IC. In a similar study, Moravec (2007) also used a four-point Likert scale to rate items in the Delphi instrument. According to Garland (1991: p. 4), “... the explicit offer of a mid-point is largely one of individual researcher preference". In the second round of the Delphi exercise, participants were also given two weeks to return their responses via email. In an attempt to increase the response rate, the round-two Delphi instrument was emailed to all those (27 Delphi nominees) who had initially agreed to take part in the research study.

Rreminder letters were despatched and follow-up calls made. Of the were with fifteen responses received (25\% attrition), n. Nine came from IC members_-and six from HM managers.

Performance measures which are interpreted as very important or important, and for which the Delphi participants arrived at a high level of consensus were retained in the second round of the Delphi exercise. However, those with low-level consensus were re-submitted to the Delphi participants for re-rating in round three of the Delphi exercise, which contained 
twenty-five performance measures. For each of these performance measures, the Delphi participants were provided with their responses and the percentage score of the entire group from round two. They were then given the choice of either maintaining or re-rating the performance measures on a Likert scale of $1-4$. The participants were the same as those who had rated the round-two Delphi questions.

\section{Results and Discussion on the Delphi Rounds - A Synopsis}

| Provided with a list of CSFs and performance measures (refer to Table II) in healthcare maintenance in IC, the Delphi participants were given the task of identifying new ones. In total, the Delphi participants were able to identify and categorise 11 new performance measures under some of the CSFs.

\section{Maintenance Resource Availability}

| -There were four performance measures under maintenance resource availability (Table II). On the provision of adequate maintenance resources in IC, an IC member commented that "... funding will never be available to resource all [maintenance] needs ..." "This is difficult as there are no national standards to indicate what is adequate in this context". For example, "the Code of Practice (Health Act) states that healthcare providers should provide adequate isolation facilities, but adequate is not defined". One healthcare maintenance manager even criticised the fact that guidance on the provision of resources to the healthcare maintenance unit in IC was an emerging issue. According to this participant, "the condition of the estate in relation to infection control needs to be risk assessed by the healthcare maintenance unit and the IC department... for resource needs". On the other hand, one of the healthcare maintenance managers noted, "I take guidance from IC [team] who will have confirmed costs and funding". Because the maintenance unit is not responsible for its budget, it equally does not directly handle the business of purchasing maintenance materials and products. According to one maintenance manager, this has "been outsourced by the procurement and logistics department to the EROS e-Procurement system". In another case, it was noted that the "purchasing department was often driven by lowest cost ...but in relation to infection control, not all of the cheapest products are the best".

One of the Delphi participants suggested that the word 'regularly' used in one of the performance measures was ambiguous. One of the Delphi participants noted that it would be too expensive for PFI hospitals to review the condition of hospital buildings on a regular 


\section{Maintenance Strategies}

There were initially five performance measures under maintenance strategies. On the performance measure concerning the daily check of all critical maintenance activities posing risk of HAIs, an IC member thought it "might not be good use of resources, as it may overkill the healthcare maintenance unit". However, other microbiologists thought that a daily check of critical maintenance systems posing the risk of HAIs might be useful, but that it was currently unavailable. A healthcare maintenance manager pointed out that "...all critical maintenance systems are monitored through a BMS system". A BMS (Building Management System) is a computer-based system that is installed in a building to monitor the building's mechanical and electrical equipment, e.g. heating, ventilation. According to this healthcare maintenance manager, it is important that "preventive maintenance in the BMS be conducted according to various frequencies to meet manufacturers' maintenance requirements and compliance with statutory requirements...". The Built Environment Group is responsible for keeping records of the effectiveness of all critical maintenance equipment/assets that may cause HAI.

Although it is important to categorise hospital assets and maintenance equipment into significant and non-significant items, it was unnecessary to do so in every area of the hospital, noted a microbiologist. According to this microbiologist, "certain areas of the hospital will, by its nature, pose a higher risk to patients e.g. augmented care areas (ICU Neonatal, renal, eancer unitscancer units and burns units) ...water systems and equipment are of a higher risk in these areas than in lower risk area, even though the equipment and services used are the same". In order to uphold high standards in critical patient areas, this 
microbiologist recommended hospital assets and maintenance equipment be validated, verified, monitored and tested. In this way, authorities can “... prove the effectiveness of the maintenance programme and ensure that equipment parameters are all maintained within specification"

Following the comments and suggestions provided by the Delphi participants, three new performance measures were included under maintenance strategies. These are:

4. Prioritization of building defects to minimize the risk of HAIs.

5. Application of an information based computer system to promote the mobility of maintenance staff.

6. The development of a water safety plan by the maintenance and Infection Control Teams (ICT).

\section{Infection Control Practices}

The CSF 'infection control practice' was divided into cleaning, transport, and administrative requirements. In total, there were 17 performance measures under this CSF. On the prevention of dust contamination, a microbiologist noted that "any building site/or building should be double screened to stop dust entering hospital streets and wards". Before commencing any maintenance with the potential of generating dust, contractors should be familiarised with dust abatement techniques, and provided with personal protective equipment. Besides protecting healthcare maintenance staff from HAIs, it is also necessary to prevent healthcare maintenance staff from transmitting HAIs in hospitals. At the moment, according to one of the healthcare maintenance managers, there is no system in place for preventing "contracted staff with the symptom of an infection e.g. diarrhoea [from] working in a clinical area". One of the healthcare maintenance managers, with over 32 years of experience working for the NHS, doubted the value of the performance measure concerning the immunisation of maintenance staff to prevent the spread of HAIs. According to this official, "the cost of this immunisation programme would be significant and also impossible to manage and control given the number of contractors on site every year". An IC member noted that "... good infection control practice and hygiene practice in [maintenance] should be sufficient to ensure adequate HAI controls". Analysis of Delphi round one resulted in the identification of three new performance measures under infection control practices. All the three newly identified performance measures were under the sub-category 'administrative requirements'. The following performance measures were identified: 
7. Establish clear guideline for the in-house staff and contractors

8. Develop a work culture that supports prioritization of maintenance work

9. Establish an agreed HAI plan to control all contract works on site.

\section{Liaison and Communication with the Infection Control Team (ICT)}

Most Delphi participants agreed that 'liaison and communication with the Infection Control Team' is an important CSF in healthcare maintenance to control HAIs. One healthcare maintenance manager even suggested for "estates staff and infection control staff to meet on a weekly basis to review all estates works programmes and agree all HAI control measures during all works". This could also allow them to "review trends or concerns in relation to microbiological monitoring”. The organisational structure for healthcare maintenance in IC has to be led by the Infection Control Team, since they are the experts in the field of IC. Under liaison and communication with the Infection Control Team, the Delphi participants did not identify any new performance measure.

\section{Service Level Agreement}

In order to draw up service level agreements (SLAs) that consider IC, healthcare maintenance managers and IC members should work closely together. Unfortunately, this is not always the case. According to an infection control nurse, “... infection control team members are rarely informed about maintenance contracts". One healthcare maintenance manager suggested that because "the selection of contractors is based on European legislation, all contracts will no doubt meet the requirements of the areas mentioned'. Presently, issues relating to arrangements to respond to emergency calls, procedures to supervise maintenance work and variables, contractors' safe record keeping are currently, according to one healthcare maintenance manager, not being considered in SLAs. Instead of selecting contractors based on strong technical, resource, managerial, and communication capabilities, NHS Trusts always "... run for the cheap option", says a microbiologist.

In order to improve the performance of the healthcare maintenance unit in IC, one of the healthcare maintenance managers proposed a number of criteria for the selection of contractors. These included, for example, evidence that the contractor has successfully executed a similar contract in an NHS Trust, association with a professional body or organisation (Legionella Control Association, UKAS accredited body). The comments and 


\begin{abstract}
suggestions under SLA led to a deeper understanding and refinement of the performance
\end{abstract} measures.

\title{
Customer Satisfaction
}

The Delphi participants did not engage in much discussion about the performance measures that were categorised under the CSF called customer satisfaction. However, they identified two new performance measures:

10. Speed of response to complaints about completed maintenance work.

11. Record of completed maintenance jobs that fail to meet required standard.

The results gathered from the round-one Delphi exercise were used to refine the subsequent Delphi instruments. In the second round, the Delphi participants achieved high-level consensus on 42 performance measures. For example, they agreed on the suggestion that healthcare maintenance managers should seek early consultation and authorisation from the infection control team on maintenance works which posed a risk of HAIs. Other important performance measures included the requirement that healthcare maintenance managers should seek advice from the infection control team on matters relating to IC, and so on.

At the end of the second round of the Delphi exercise, participants failed to achieve highlevel consensus on 20 performance measures. However, five additional performance indicators were introduced from the first round of the Delphi exercise so that in the third round of the Delphi exercise, participants were presented with 25 performance measures for re-rating. In the third round of the Delphi exercise, high-level consensus was achieved on 11 performance measures. These included for example the maintenance and infection control team members developing a water safety plan to control the risk of waterborne infections in hospitals. At the end of the third round of the Delphi exercise, there were 14 performance measures with low-level consensus amongst the Delphi participants. These performance measures are less important in the control of maintenance-associated HAIs in hospitals. No further Delphi rounds were conducted after the third round. Further reading about the results of the second and third rounds of the Delphi exercises are covered by the same authors in the International Journal of Health care Quality Assurance, Volume, 28; Issue, 7. 


\section{Conclusion}

This research shows the different processes leading to the application of the Delphi technique to identify the CSFs and performance measures in the control of maintenance associate infections. For example, in-depth literature was conducted to identify the pertinent research issues about the research topic under investigation. The document analyses process resulted in the identification of the relevant documents, to identify the research and interview questions. These questions were used to conduct an exploratory case study with Acute NHS Trust. The results of the exploratory case study suggested that the Delphi technique as suitable research method for conducting further investigation.

So far, the Delphi technique has been criticised for a number of reasons including a lack of reliability, validity and credibility (Hsu and Sandford, 2007). According to Sackman (1974: p. 12), this may be caused by issues related to the "neglect of standard experimental guidelines" in the implementation of the Delphi technique. In the current research, in-depth literature review has been conducted about the key stages in the application of the Delphi technique. This includes issues that are related to the design and administration of Delphi questions, participant selection, data analysis, and Delphi rounds. These issues are critical in the application of the Delphi technique in researches of this nature.

The detail in the application of the Delphi technique resulted in high level iteration between the infection control members and healthcare maintenance managers in the identification of 11 performance measures not cited in relevant research material. These performance measures are drawn from the following CSFs 'maintenance resources availability', 'maintenance strategies', 'infection control practices' and 'customer satisfaction'. These areas are critical in the control of maintenance associated infections.

\section{References}

Boote, J., Barber, R. and Cooper, C. (2006), "Principles and Indicators of Successful Consumer Involvement in NHS Research: Results of a Delphi study and Subgroup Analysis", Health Policy, Vol. 75 No. 3, pp. 280-297.

Dalkey, N. and Helmer, O. (1963), "An Experimental Application of the Delphi Method to the use of Experts", Management Science, Vol. 9 No. 3, pp. 458-467.

Day, J. and Bobeva, M. (2005), "A Generic Toolkit for the Successful Management of Delphi Studies", Electronic journal of business research methods, Vol. 3 No. 2, pp. 103-116. 
Faucher, J., Everett, A. M. and Lawson, R. (2008), “Applying a Modified Delphi Approach to Determine the Current State of the Concept of Knowledge", available at: https://decisionsciences.org/Proceedings/DSI2008/docs/480-4598.pdf (accessed 4 July 20013).

Garland, R. (1991), “The Mid-point on a Rating Scale: is it Desirable?" Marketing Bulletin, Vol. 2, pp. 66-70.

Garson, D. (2012), “Testing Statistical Assumptions”, North Carolina State University, USA.

Gordon, T. (1994), "The Delphi Method. AC Millennium Project", available at: http://www.gerenciamento.ufba.br/Downloads/delphi\%20\%281\%29.pdf (accessed 23 February 2013).

Green, H., Hunter, C. and Moore, B. (1990), "Application of the Delphi Technique in Tourism”, Annals of Tourism Research, Vol. 17 No. 2, pp. 270-279.

Gupta, U. G. and Clarke, R. E. (1996), “Theory and Applications of the Delphi Technique: A bibliography (1975-1994)", Technological Forecasting and Social Change, Vol. 53 No. 2, pp. 185-211.

Hallowell, M. R. and Gambatese, J. A. (2010), "Qualitative Research: Application of the Delphi Method to CEM Research", Journal of Construction Engineering and Management, Vol. 136 No. 1, pp. 99-107.

Hanafin, S. (2004), "Review of Literature on the Delphi Technique", National Children's Office, available at: http://www.childrensdatabase.ie/documents/publications/Delphi_Technique_A_Literatur e_Review.pdf (accessed 20 January 2013).

Hsu, C. and Sandford, B. (2007), "The Delphi Technique: Making Sense of Consensus", Practical Assessment, Research and Evaluation, Vol. 10 No. 12, pp. 1-8.

Joseph, A. (2006), "The Impact of Environment on Infections in Healthcare Facilities", Centre for Health Design.

Kalaian, S. and Kasim, R. (2012), "Terminating Sequential Delphi Survey Data Collection", Practical Assessment, Research and Evaluation, Vol. 17 No. 5, pp. 1-10.

Keeney, S., Hasson, F. and McKenna, H. P. (2001), "A Critical Review of the Delphi Technique as a Research Methodology for Nursing", International Journal of Nursing Studies, Vol. 38 No. 2, pp. 195-200.

Linstone, H. A. and Turoff, M. (Eds.) (2002), "General Applications", The Delphi Method: Techniques and Applications, Addison-Wesley, Reading, MA. 
McDonald, J. (2009), Handbook of Biological Statistics, Sparky House Publishing, Baltimore, USA.

Moravec, J. (2007), "A New Paradigm of Knowledge Production in Minnesota Higher Education: A Delphi Study", University of Minnesota, USA.

Parliamentary Office of Science and Technology. (2003), "Food Poisoning, January 2003", POST Note, UK Parliament.

Powell, C. (2003), "The Delphi Technique: Myths and Realities", Journal of Advanced Nursing, Vol. 41 No. 4, pp. 376-382.

Sackman, H. (1974), Delphi assessment: Expert opinion, forecasting and group process, Santa Monica, CA: Rand Corporation.

Rayens, M. K. and Hahn, E. J. (2000), "Building Consensus Using the Policy Delphi Method", Policy, Politics and Nursing Practice, Vol. 1 No. 4, pp. $308-315$.

Sackman, H. 1974, Delphi Critique; Expert Opinion, Forecasting, and Group Process, Lexington Books.

Skulmoski, G. J., Hartman, F. T. and Krahn, J. (2007), "The Delphi Method for Graduate Research", Journal of Information Technology Education, Vol. 6, pp. 1-21.

Somerville, J. A. (2007), "Critical factors affecting the meaningful assessment of student learning outcomes: A Delphi study of the opinions of community college personnel”, Oregon State University, Corvallis, OR.

Performance Management, Vol. 56 No. 1, 25-59.

Tsang, A. H. C. (1998), "A strategic approach to managing maintenance performance", Journal of Quality in Maintenance Engineering, Vol. 4 No. 2, pp. 87-94.

Turoff, M. (2002), “The Policy Delphi”, Linstone, H. A. and Turoff, M. (Eds.), The Delphi Method: Techniques and Applications, Addison-Wesley, Reading, MA.

Yin, R. K. (1993). Applications of Case Study Research, Sage Publications, London.

Formatted: Font: Italic

Formatted: Font: Italic 